\title{
Effects of two $\beta_{3}$-adrenoceptor agonists, SR 58611A and BRL 37344, and of salbutamol on cholinergic and NANC neural contraction in guinea-pig main bronchi in vitro
}

\author{
'Corinne A.E. Martin, Emmanuel Naline, *Luciano Manara \& Charles Advenier
}

Département de Pharmacologie, Faculté de Médecine Paris-Ouest, 15 rue de l'Ecole de Médecine, F-75270 Paris Cedex 06, France and *SANOFI-MIDY S.p.A. Research Center, via Piranesi 38, 20137 Milan, Italy

1 The aim of the present study was to investigate the type of adrenoceptor which modulates constriction of the guinea-pig isolated main bronchus in response to electrical field stimulation (EFS). Drugs used were salbutamol and two agonists reportedly selective for the putative $\beta_{3}$-adrenoceptor: BRL 37344 and SR 58611A.

2 At basal tone, all three drugs induced relaxation, however, SR 58611A and BRL $37344\left(10^{-9}\right.$ to $\left.10^{-6} \mathrm{M}\right)$ relaxed guinea-pig isolated main bronchus more weakly than salbutamol $\left(10^{-9}\right.$ to $\left.10^{-6} \mathrm{M}\right)$. The effects observed at $10^{-6} \mathrm{M}$ were $43 \% \pm 9 \%, 63 \% \pm 4 \%$ and $98 \% \pm 1 \%$ of the maximal effect induced by theophylline $\left(3 \times 10^{-3} \mathrm{M}\right)$ for SR 58611A, BRL 37344 and salbutamol, respectively.

3 SR $58611 \mathrm{~A}$ and BRL $37344\left(10^{-8}\right.$ to $\left.10^{-6} \mathrm{M}\right)$ did not significantly modify the cholinergic component of the response to EFS, but caused a concentration-dependent reduction of the nonadrenergic noncholinergic (NANC) excitatory component $\left(41.8 \% \pm 10.1 \%\right.$ and $56.8 \% \pm 7.4 \%$ respectively at $10^{-6} \mathrm{M}$, $n=6-7)$. Salbutamol $\left(10^{-9}\right.$ to $\left.10^{-7} \mathrm{M}\right)$ strongly inhibited both components, with $91.1 \% \pm 4.2 \%$ of inhibition for the NANC contraction and $62.0 \% \pm 5.2 \%$ of inhibition for the cholinergic contraction $\left(10^{-7} \mathrm{M}, n=7\right)$.

4 Whereas the inhibitory effects of salbutamol were strongly inhibited by both propranolol $\left(10^{-6} \mathrm{M}\right)$ and ICI $118,551\left(10^{-6} \mathrm{M}\right)$, those of BRL 37344 were only slightly, albeit significantly reduced by both propranolol and ICI 118,551, and those of SR 58611A were unaffected by treatment with either $\beta$-adrenoceptor antagonist. An $\alpha_{2}$-adrenoceptor antagonist, yohimbine, did not influence the inhibitory effects of any of the $\beta$-adrenoceptor agonists tested.

5 Concentration-response curves to acetylcholine $\left(10^{-8}\right.$ to $\left.10^{-3} \mathrm{M}\right),\left[\mathrm{Nle}^{10}\right] \mathrm{NKA}(4-10)\left(10^{-10}\right.$ to $\left.10^{-6} \mathrm{M}\right)$ and substance $\mathrm{P}\left(10^{-10}\right.$ to $\left.3 \times 10^{-6} \mathrm{M}\right)$ were also significantly shifted to the right by salbutamol $\left(10^{-6} \mathrm{M}\right)$, whereas SR 58611A and BRL $37344\left(10^{-6} \mathrm{M}\right)$ had no effect.

6 These results suggest that the stimulation of putative $\beta_{3}$-adrenoceptors exerts a specific prejunctional inhibitory action on NANC excitatory response induced by EFS of the isolated main bronchus of the guinea-pig. They also suggest that a $\beta_{2}$-adrenoceptor agonistic component may be involved in the effects of BRL 37344.

Keywords: $\beta_{3}$-Adrenoceptors; electrical field stimulation; guinea-pig isolated main bronchi; NANC-induced contraction

\section{Introduction}

It is now clearly recognized that stimulation of many types of receptor can influence the release of neurotransmitters from airway nerves and this is likely to be important in the physiological control of airway functions. Indeed, the stimulation of $\alpha_{2}$ or $\beta$-adrenoceptors, muscarinic $M_{2}$, vasoactive intestinal peptide, neuropeptide $Y$, opioid, GABA, histamine $\mathrm{H}_{3}$, and prostanoid EP-receptors decreases the cholinergic and/or the excitatory nonadrenergic noncholinergic responses to electrical field stimulation (EFS) of airways (Barnes, 1992). The characterization of the two components of the response to EFS as cholinergic and as nonadrenergic noncholinergic has previously been demonstrated in several studies. Tetrodotoxin abolishes both components indicating that both are neurogenic in nature. The early, transient contraction is inhibited by atropine and results from stimulation of cholinergic nerves. The late and prolonged second phase is nonadrenergic noncholinergic (NANC) in nature and is abolished or strongly reduced by antagonists of $\mathrm{NK}_{2}$ - receptors, such as SR 48968 and MEN 10,207, and partially reduced by CP-96,345, an antagonist of $\mathrm{NK}_{1}$-receptors (Lundberg et al., 1983; Maggi et al., 1991; Martin et al., 1992).

The $\beta$-adrenoceptor mediating the modulatory effect of catecholamines on cholinergic nerves is however disputed. In

\footnotetext{
'Author for correspondence.
}

canine airways, the presence of prejunctional $\beta_{1}$-adrenoceptors is suggested, since metoprolol, a $\beta_{1}$-adrenoceptor antagonist, is effective in inhibiting the modulatory effects of catecholamines on cholinergic nerves (Danser et al., 1987; Ito, 1988). In human bronchi, $\beta_{2}$-adrenoceptors mediate the inhibitory response of catecholamines on cholinergic nerves, since isoprenaline is more potent than adrenaline and noradrenaline, and since a $\beta_{2}$-selective antagonist ICI 118,551 completely blocks the modulatory effect of isoprenaline, whereas the $\beta_{1}$-selective antagonist, betaxolol, is ineffective (Rhoden et al., 1988). Furthermore, the selective $\beta_{2}$-adrenoceptor agonist, procaterol, is also effective in inhibiting cholinergic neurotransmission in human airways (Aizawa et $a l ., 1991)$. The $\beta_{2}$-adrenoceptor agonists, salbutamol and formoterol, also inhibit both cholinergic and NANC excitatory bronchoconstriction in guinea-pig bronchi in vitro, and these effects were ascribed to a presynaptic inhibition of mediator release since these drugs were much more effective as inhibitors of the EFS than the matched contractile response induced by substance $\mathrm{P}$ or acetylcholine (Verleden et al., 1991).

Recently, Itabashi et al. (1992) reported that BRL 35135 and BRL 37344, two putative $\beta_{3}$-adrenoceptor agonists, reduced NANC contraction of the guinea-pig bronchus induced by capsaicin or by EFS in a concentration-dependent fashion without having a significant effect on the contraction 
induced by substance $P$ and having a significant effect at concentrations above $10^{-8} \mathrm{M}$ for BRL 35135 and BRL 37344 respectively, suggesting that a $\boldsymbol{\beta}_{3}$-adrenoceptor might exert a prejunctional inhibitory action on NANC contractions.

The purpose of the present study was to investigate the modulating effects of SR 58611A, a new putative $\beta_{3}$-adrenoceptor agonist (Bianchetti \& Manara, 1990), on neurogenic contraction of the guinea-pig isolated main bronchus induced by EFS. The effects of SR 58611A were compared with those of SR 58825A, its inactive (+)-enantiomer, and of BRL 37344 , another putative $\beta_{3}$-adrenoceptor agonist (McLaughlin \& MacDonald, 1990; Itabashi et al., 1992; Webber \& Stock, $1992)$ and of the selective $\beta_{2}$-adrenoceptor agonist, salbutamol.

\section{Methods}

\section{Tissue preparation}

Guinea-pig main bronchial rings were obtained from tricoloured guinea-pigs of either sex (250-350 g) anaesthetized with urethane $\left(1.25 \mathrm{~g} \mathrm{~kg}^{-1}\right.$, i.p.) and were suspended under an initial tension of $2.0 \mathrm{~g}$ in Krebs solution at $37^{\circ} \mathrm{C}$ gassed with $95 \% \quad \mathrm{O}_{2}: 5 \% \quad \mathrm{CO}_{2}$. After $1 \mathrm{~h}$ of equilibration, resting tension was between 1.5 and $2.0 \mathrm{~g}$. Under these conditions, responses to agonists were reproducible over several hours. Changes in tension were measured isometrically with Pioden strain gauges (UF-1) and amplifiers (EMKA, France), and displayed on a recorder (Linseis L65514, France). The composition of the $\mathrm{Krebs}$ solution was (mM): $\mathrm{NaCl} 118.0$, $\mathrm{KCl}$ 5.4, $\mathrm{CaCl}_{2} 2.5, \mathrm{KH}_{2} \mathrm{PO}_{4} 1.2, \mathrm{MgSO}_{4} 1.2, \mathrm{NaHCO}_{3} 25.0$ and glucose 11.7 .

In all experiments, after an equilibration period of $60 \mathrm{~min}$, guinea-pig bronchial rings were contracted with acetylcholine $10^{-3} \mathrm{M}$ and relaxed to maximal relaxation with theophylline $3 \times 10^{-3} \mathrm{M}$, then allowed to equilibrate for a further $60 \mathrm{~min}$ while they were washed with Krebs solution every $15 \mathrm{~min}$.

\section{Cumulative concentration-response curves}

In a first series of experiments, preparations were allowed to remain under resting tension, then SR 58611A, SR 58825A, BRL 37344 or salbutamol $\left(10^{-9}\right.$ to $\left.10^{-6} \mathrm{M}\right)$ cumulative concentration-response curves were obtained by addition of these compounds every 10-20 min until a plateau was reached. The relaxant effects of these drugs were expressed as percentages of the maximal relaxation induced by theophylline $\left(3 \times 10^{-3} \mathrm{M}\right)$.

In a second series of experiments, the inhibitory effects of SR 58611A $\left(10^{-6} \mathrm{M}\right)$, BRL $37344\left(10^{-6} \mathrm{M}\right)$ or salbutamol $\left(10^{-6} \mathrm{M}\right)$ used as pretreatment were studied. After $30 \mathrm{~min}$ preincubation, cumulative concentration-response curves to acetylcholine $\left(10^{-8}\right.$ to $\left.10^{-3} \mathrm{M}\right),\left[\mathrm{Nle}^{10}\right] \mathrm{NKA}(4-10)\left(10^{10}\right.$ to $\left.10^{-6} \mathrm{M}\right)$ or substance $\mathrm{P}\left(10^{-10}\right.$ to $\left.3 \times 10^{-6} \mathrm{M}\right)$ were obtained by addition of these compounds every 5-10 min until a plateau was reached. Spasmogen-induced contractions were expressed as a percentage of the contraction induced by control acetylcholine $\left(10^{-3} \dot{\mathrm{M}}\right)$. The experiments with $\left[\mathrm{Nle}^{10}\right.$ ] NKA $(4-10)$ and substance $P$ were performed in the presence of phosphoramidon $\left(10^{-5} \mathrm{M}\right)$ to avoid an inhibition of their effects by metabolism (Devillier et al., 1988).

\section{Electrical field stimulation}

Experiments were performed in organ baths fitted with two platinum plate electrodes $\left(1 \mathrm{~cm}^{2}\right)$ placed alongside the tissue (10 mm apart) for transmural electrical field stimulation (EFS: biphasic pulse width $1 \mathrm{~ms}$, constant current of $320 \mathrm{~mA}$, frequency of $16 \mathrm{~Hz}$ for $10 \mathrm{~s}$ ) (Szolcsanyi \& Bartho, 1982; Undem et al., 1990). To avoid indirect effects of prostaglandins on the neuronal responses, indomethacin $10^{-6} \mathrm{M}$ was added to the Krebs solution at the beginning and for the duration of the experiment. The preparation was allowed to remain under resting tension, then was stimulated every 30-45 min with a stimulator (EMKA, France) in which the voltage output was adjusted to give a constant current of $320 \mathrm{~mA}$ and which produced biphasic rectangular pulses of alternating polarity. Control experiments $(n=10)$ showed no significant fading of the response to EFS during the experimental period. These stimulus parameters caused an optimal reproducible biphasic contraction which consisted of a fast contraction followed by a sustained contractile response, both abolished by tetrodotoxin. The first, fast component is inhibited by atropine and results from stimulation of cholinergic nerves. The late and prolonged second phase is NANC in nature, and is abolished or strongly reduced by antagonists of $\mathrm{NK}_{2}$-receptors, such as SR 48968 and MEN 10,207 , and partially reduced by CP-96,345, an antagonist of $\mathrm{NK}_{1}$-receptors (Lundberg et al., 1983; Maggi et al., 1991; Martin et al., 1992). We also have previously observed that atropine $10^{-6} \mathrm{M}$ did not modify the NANC response and similarly, SR $48968\left(10^{-10}\right.$ to $\left.10^{-7} \mathrm{M}\right)$ did not modify the cholinergic response (Martin et al., 1992), suggesting that in these experimental conditions no interaction between cholinergic and NANC responses. was involved. These procedures were repeated in the absence or presence of SR 58611A $\left(10^{-8}\right.$ to $\left.10^{-6} \mathrm{M}\right)$, SR 58825A $\left(10^{-8}\right.$ to $\left.10^{-6} \mathrm{M}\right)$, BRL $37344\left(10^{-8}\right.$ to $\left.10^{-6} \mathrm{M}\right)$ or salbutamol $\left(10^{-9}\right.$ to $\left.10^{-7} \mathrm{M}\right)$ which were added to the bath $30 \mathrm{~min}$ before the application of EFS. To determine what type of $\beta$-adrenoceptor was involved in these responses we used propranolol $\left(10^{-6} \mathrm{M}\right)$, ICI $118,551\left(10^{-6} \mathrm{M}\right)$ and yohimbine $\left(10^{-6} \mathrm{M}\right)$ as pretreatment $30 \mathrm{~min}$ before the application of EFS and/or the incubation of $\beta$-adrenoceptor agonists.

\section{Statistical analysis of results}

Data are expressed as mean \pm s.e.mean. Statistical analysis of the results was performed with variance analysis and Student's $t$ test for paired or unpaired data, as appropriate. Probability values of $P<0.05$ were considered significant.

\section{Drugs}

The substances used were: acetylcholine $\mathrm{HCl}$ ( $\mathrm{PCH}$, Paris); BRL 37344 (sodium-4 [2 [2-hydroxy-2(3-chlorophenyl)ethylamino]propyl]phenoxyacetate), ICI 118,551 (erythro ( \pm )-1(7-methylindan-4-yloxy) -3-isopropylaminobutan-2-ol-hydrochloride), SR 58611A (ethyl\{(7S)-7-[(2R)-2-(3-chlorophenyl)-

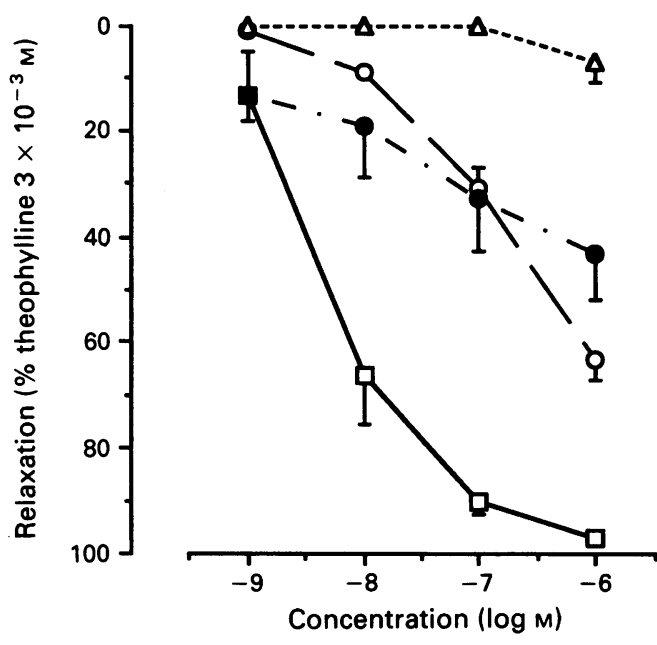

Figure 1 Cumulative relaxant concentration-response curves to salbutamol (口), BRL $37344(O)$, SR 58611A $(\odot)$ and SR 58825A $(\Delta)$ $\left(10^{-9}\right.$ to $\left.10^{-6} \mathrm{M}\right)$ on guinea-pig isolated main bronchi against basal tone $(n=4-5)$. Values are means \pm s.e.mean. 

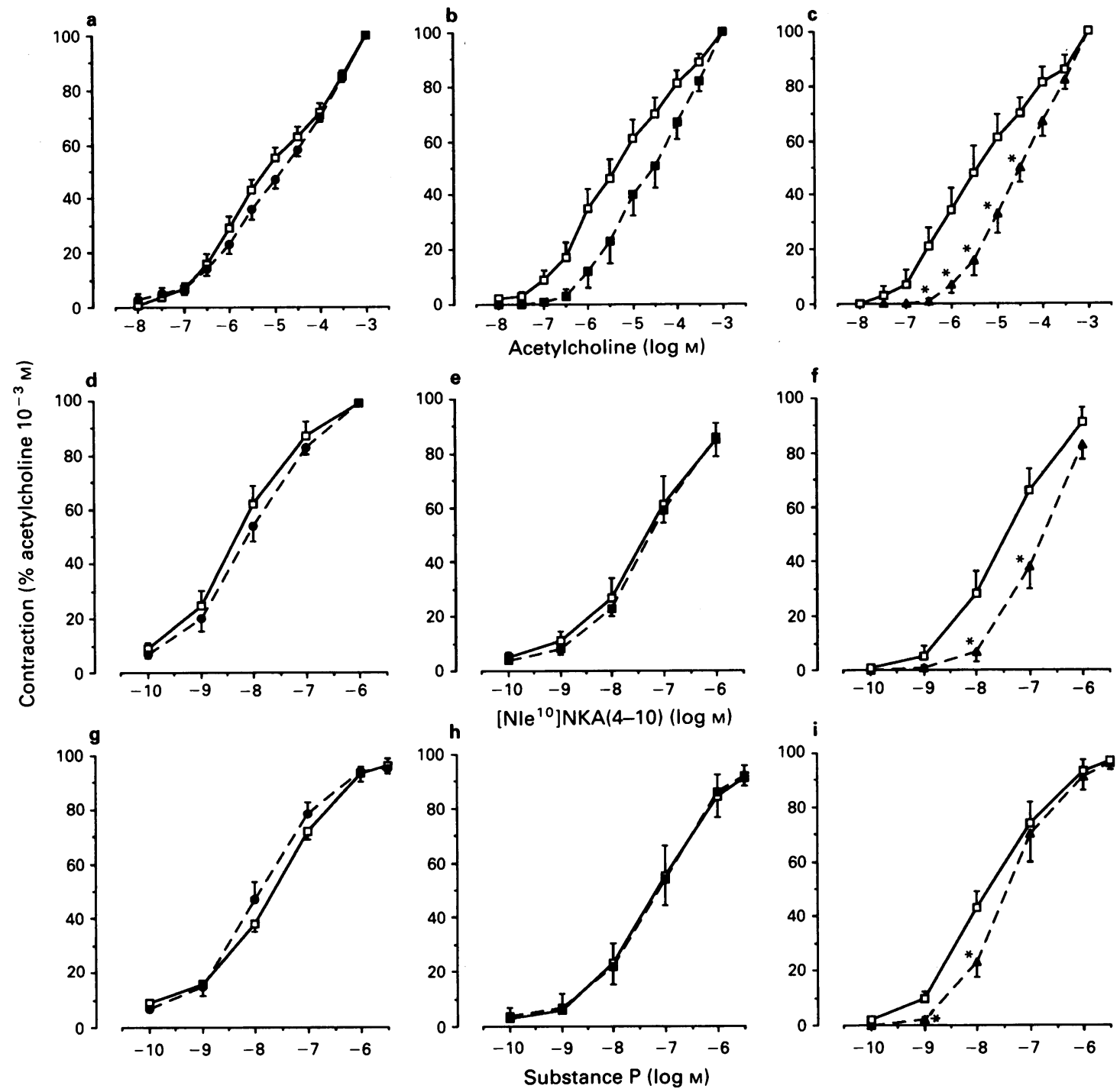

Figure 2 Cumulative contractile concentration-response curves to acetylcholine $(a, b, c),\left[N^{10}\right]$ NKA(4-10) (d,e,f) and substance $P$ $(\mathrm{g}, \mathrm{h}, \mathrm{i})$ in the absence (control, $\square)$ or in the presence of SR 58611A $\left(0,10^{-6} \mathrm{M}\right.$; a,d and g), BRL $37344\left(\mathrm{G}, 10^{-6} \mathrm{M} ; \mathrm{b}, \mathrm{e}\right.$ and $\left.\mathrm{h}\right)$ or salbutamol $\left(\Delta, 10^{-6} \mathrm{M} ; \mathrm{c}, \mathrm{f}\right.$ and i) in guinea-pig isolated main bronchi $(n=4-6)$. Values are means \pm s.e.mean. Significant differences from control are indicated by: ${ }^{*} P<0.05$.

2-hydroxyethylamino] 5,6,7,8 -tetrahydronaphthalen-2-yloxy\} acetate, hydrochloride), SR 58825A (ethyl\{(7R)-7-[(2S)-2-(3chlorophenyl)-2-hydroxyethylamino] -5,6,7,8-tetrahydronaphthalen-2-yloxy\} acetate, hydrochloride) (gift from SanofiMidy, S.p.A. Research Center, Milan, Italy); indomethacin (Merck); [Nle $\left.{ }^{10}\right]$ NKA(4-10) (Novabiochem, Paris, France); phosphoramidon, propranolol, salbutamol, substance $\mathrm{P}$, yohimbine (Sigma, St Louis, U.S.A.); theophylline sodium anisate (Bruneau, Paris, France). All drugs were dissolved in distilled water and then diluted in Krebs solution, except indomethacin which was dissolved in ethanol and then diluted in Krebs solution. The maximal amount of ethanol added to the bath $(0.4 \%)$ did not alter the reactivity of the guinea-pig bronchial preparations to acetylcholine.

\section{Results}

Effects of SR 58611A, SR 58825A, BRL 37344 and salbutamol on basal tone of guinea-pig bronchi

The relaxant effects of SR 58611A, BRL 37344 and SR 58825A $\left(10^{-9}\right.$ to $\left.10^{-6} \mathrm{M}\right)$ were examined on preparations at basal tone. SR 58611A and BRL 37344 produced concen- tration-dependent falls in basal tone reaching $43 \% \pm 9 \%$ and $63 \% \pm 4 \%$ of maximal response to theophylline $3 \times 10^{-3} \mathrm{M}$, respectively $\left(10^{-6} \mathrm{M}, n=4-5\right)$ (Figure 1). In contrast, salbutamol induced a full relaxation at $10^{-6} \mathrm{M}$, with a $\mathrm{pD}_{2}$ of $8.3 \pm 0.2(n=4)$, whereas SR 58825A, the inactive enantiomer of SR 58611A, had no significant effect on the basal tone of guinea-pig isolated main bronchus $(7 \% \pm 4 \%$, $\left.10^{-6} \mathrm{M}, n=4\right)$ (Figure 1). SR 58611A and BRL 37344 were approximately 100 times less potent than salbutamol.

Effects of SR 58611A, BRL 37344 or salbutamol on cumulative concentration-response curves to acetylcholine, [Nle $\left.{ }^{10}\right] N K A(4-10)$ and substance $P$ on guinea-pig isolated main bronchi

SR 58611A $\left(10^{-6} \mathrm{M}\right)$ and BRL $37344\left(10^{-6} \mathrm{M}\right)$ did not significantly modify concentration-response curves to acetylcholine $\left(10^{-8}\right.$ to $\left.10^{-3} \mathrm{M}\right)$, [Nle $\left.{ }^{10}\right] \mathrm{NKA}(4-10)\left(10^{-10}\right.$ to $10^{-6}$ $\mathrm{M})$ or substance $\mathrm{P}\left(10^{-10}\right.$ to $\left.3 \times 10^{-6} \mathrm{M}\right)$, although $\mathrm{BRL}$ 37344 did cause a small apparent rightward shift of the concentration-response curve to acetylcholine, whereas salbutamol $\left(10^{-6} \mathrm{M}\right)$ produced significant rightward shifts of the concentration-response curves to acetylcholine, $\left[\mathrm{Nle}^{10}\right] \mathrm{NKA}$ (4-10) and substance $P$, with no apparent depression of maximum response (Figure 2). 


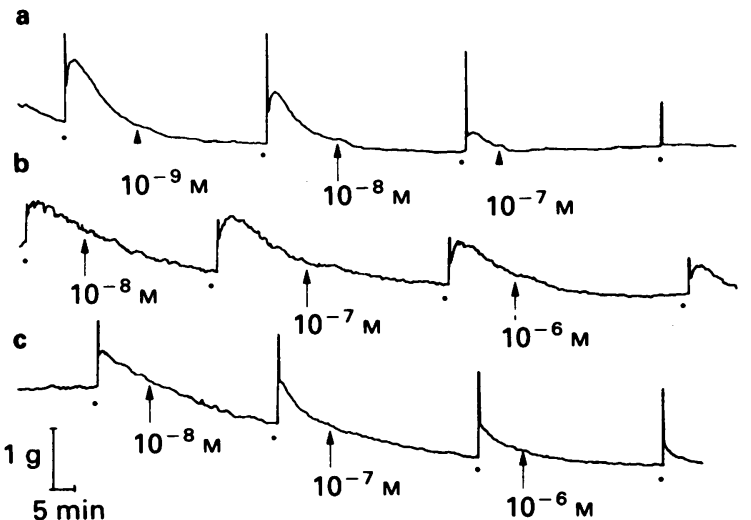

Figure 3 Representative tracings of the biphasic contraction induced by EFS of guinea-pig isolated main bronchi $(0: 16 \mathrm{~Hz}, 1 \mathrm{~ms}$, $320 \mathrm{~mA}$ for $10 \mathrm{~s}$; in the presence of indomethacin $10^{-6} \mathrm{M}$ ) and of the effects of salbutamol $\left(\mathrm{a}, 10^{-9}\right.$ to $\left.10^{-7} \mathrm{M}\right)$, BRL $37344\left(\mathrm{~b}, 10^{-8}\right.$ to $10^{-6} \mathrm{M}$ ) and SR $58611 \mathrm{~A}\left(\mathrm{c}, 10^{-8}\right.$ to $10^{-6} \mathrm{M}$ ).

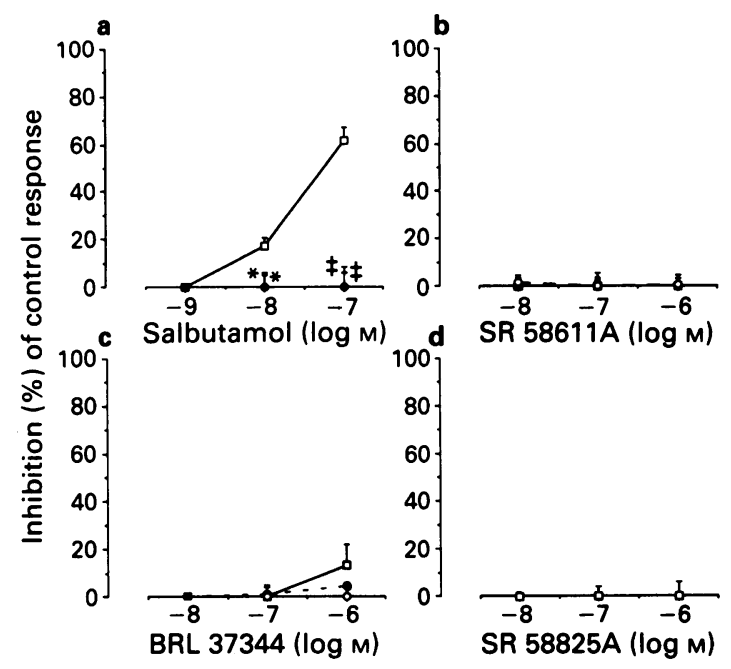

Figure 4 Concentration-response curves illustrating the inhibition (\%) of the cholinergic component of the response to EFS of guineapig isolated main bronchi by salbutamol $\left(\mathrm{a}, 10^{-9}\right.$ to $10^{-7} \mathrm{M}$ ), SR $58611 \mathrm{~A}$ (b, $10^{-8}$ to $10^{-6} \mathrm{M}$ ), BRL 37344 (c, $10^{-8}$ to $10^{-6} \mathrm{M}$ ) and SR 58825A (d, $10^{-8}$ to $10^{-6} \mathrm{M}$ ) in the absence $(\square)$ and presence of propranolol $\left(O, 10^{-6} \mathrm{M}\right)$, ICI $118,551\left(\mathrm{O}, 10^{-6} \mathrm{M}\right)$. Experiments were performed in the presence of indomethacin $10^{-6} \mathrm{M}$. Means \pm s.e.mean of 5 to 7 animals are shown. Significant differences from agonists in the absence of pretreatment with $\beta$-adrenoceptor antagonists are indicated by: ${ }^{*} P<0.05$ and $\ddagger P<0.001$.
Effects of SR 58611A, SR 58825A, BRL 37344 and salbutamol on the responses induced by electrical field stimulation (EFS)

Figure 3 shows representative recordings of the biphasic contraction induced by EFS and their modification by salbutamol, BRL 37344 and SR 58611A. SR 58611A and BRL $37344\left(10^{-8}\right.$ to $\left.10^{-6} \mathrm{M}\right)$ did not significantly modify the cholinergic response to EFS (Figure 4), but significantly inhibited the NANC contraction induced by EFS, producing $41.8 \% \pm 10.1 \%(n=7)$ and $56.8 \% \pm 7.4 \%(n=6)$ inhibition respectively (Figure 5 , Table 1). Under similar conditions, salbutamol $\left(10^{-9}\right.$ to $\left.10^{-7} \mathrm{M}\right)$ strongly inhibited both components of the contraction induced by EFS, but the inhibition of the NANC component was greater $(91.1 \% \pm 4.2 \%$, $\left.10^{-7} \mathrm{M}, n=7\right)$ than the inhibition of the cholinergic component $\left(62.0 \% \pm 5.2 \%, 10^{-7} \mathrm{M}, n=7\right.$ ) (Figure 4, Figure 5, Table 1).

The inhibitory effect of salbutamol on both the cholinergic and the NANC components of the contraction induced by EFS (Figure 4, Figure 5) was abolished or reduced by the
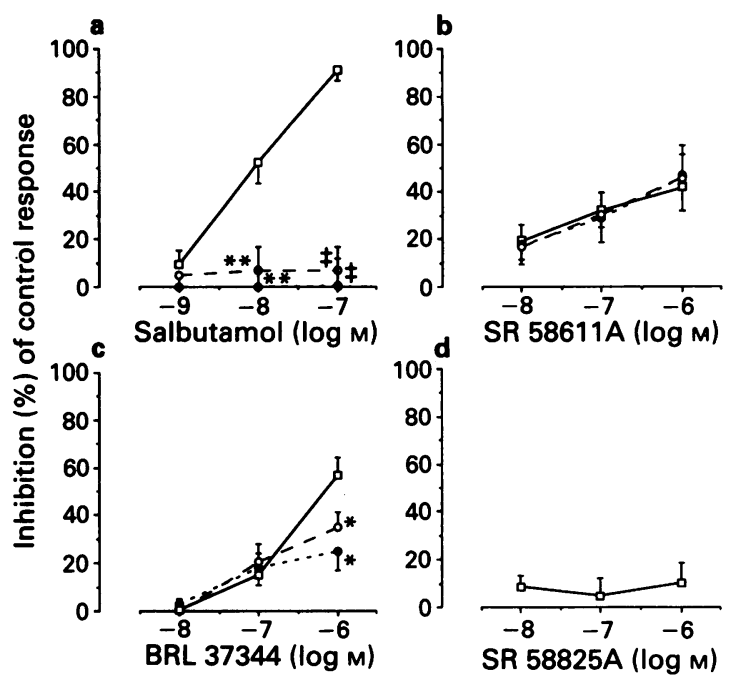

Figure 5 Concentration-response curves illustrating the inhibition (\%) of the nonadrenergic noncholinergic component of the response to EFS of guinea-pig isolated main bronchi by salbutamol $\left(\mathrm{a}, 10^{-9}\right.$ to $10^{-7} \mathrm{M}$ ), SR $58611 \mathrm{~A}\left(\mathrm{~b}, 10^{-8}\right.$ to $10^{-6} \mathrm{M}$ ), BRL 37344 (c, $10^{-8}$ to $10^{-6} \mathrm{M}$ ) and SR 58825A (d, $10^{-8}$ to $\left.10^{-6} \mathrm{M}\right)$ in the absence $(\square)$ and presence of propranolol $\left(O, 10^{-6} \mathrm{M}\right)$, ICI $118,551\left(O, 10^{-6} \mathrm{M}\right)$ Experiments were performed in the presence of indomethacin $10^{-6} \mathrm{M}$. Means \pm s.e.mean of 5 to 7 animals are shown. Significant differences from agonists in the absence of pretreatment with $\beta$ adrenoceptor antagonists are indicated by: ${ }^{*} P<0.05,{ }^{* *} P<0.01$, $\ddagger P<0.001$.

Table 1 Effects of $\beta$ - and $\alpha$-adrenoceptor antagonists on the inhibition produced by $\beta$-adrenoceptor agonists on the NANC contraction induced by electrical field stimulation of the guinea-pig main bronchus

\begin{tabular}{|c|c|c|c|c|}
\hline & $\begin{array}{c}\text { Without } \\
\text { pretreatment }\end{array}$ & $\begin{array}{l}\text { Inhibition of } c \\
\text { Propranolol } \\
\left(10^{-6} \mathrm{M}\right)\end{array}$ & $\begin{array}{c}\text { esponse (\%) } \\
\text { Pretreatment } \\
\text { ICI } 118,551 \\
\left(10^{-6} \mathrm{M}\right)\end{array}$ & $\begin{array}{c}\text { Yohimbine } \\
\left(10^{-6} \mathrm{M}\right)\end{array}$ \\
\hline $\begin{array}{l}\text { Salbutamol } \\
\left(10^{-7} \mathrm{M}\right) \\
\text { SR 58611 A } \\
\left(10^{-6} \mathrm{M}\right) \\
\text { BRL 37344 } \\
\left(10^{-6} \mathrm{M}\right)\end{array}$ & $\begin{array}{c}91.1 \pm 4.2^{\mathrm{c}} \\
(7) \\
41.8 \pm 10.1^{\mathrm{b}} \\
(7) \\
56.8 \pm 7.4^{\mathrm{c}} \\
(6)\end{array}$ & $\begin{array}{c}0.64 \pm 11.3^{* *} \\
(5) \\
46.0 \pm 13.2^{b} \\
(6) \\
25.1 \pm 7.2^{b *} \\
(6)\end{array}$ & $\begin{array}{c}6.9 \pm 9.8^{* *} \\
(6) \\
46.2 \pm 10.2^{b} \\
(5) \\
35.2 \pm 6.0^{c *} \\
(5)\end{array}$ & $\begin{array}{c}70.0 \pm 10.3^{\mathrm{c}} \\
(6) \\
30.9 \pm 10.9^{\mathrm{b}} \\
(6) \\
71.0 \pm 4.4^{\mathrm{c}} \\
(6)\end{array}$ \\
\hline
\end{tabular}

Values are means \pm s.e.mean. $(n)=$ number of guinea-pigs per group. Significant inhibitions of control response are shown as: a $P<0.05$; $^{\mathrm{b}} P<0.01$; $^{\mathrm{c}} P<0.001$. Significant differences from agonists in the absence of pretreatment with antagonists are shown as: ${ }^{*} P<0.05 ;{ }^{*} P<0.001$. 
non-selective $\beta$-adrenoceptor antagonist, propranolol, and by the selective $\beta_{2}$-adrenoceptor antagonist, ICI 118,551, but not significantly modifed by the $\alpha_{2}$-adrenoceptor antagonist, yohimbine (Figure 4, Figure 5, Table 1). Propranolol $\left(10^{-6} \mathrm{M}\right)$ and ICI $118,551\left(10^{-6} \mathrm{M}\right)$ slightly, but significantly, reduced the inhibition produced by BRL 37344 but not by SR $58611 \mathrm{~A}$ on the NANC excitatory component (Figure 4, Figure 5, Table 1).

Finally, Figures 4 and 5 show that the inactive enantiomer of SR 58611A, SR 58825A, did not influence either component of the contraction induced by EFS.

\section{Discussion}

In the present study we have compared the effects of two putative $\beta_{3}$-adrenoceptor agonists, SR 58611A and BRL 37344 , with those of salbutamol, a selective $\boldsymbol{\beta}_{2}$-adrenoceptor agonist, on the guinea-pig isolated main bronchus.

SR 58611A is a novel $\beta_{3}$-adrenoceptor agonist which belongs to the family of phenylethanolaminotetralines. This drug, unlike the $\beta$-adrenoceptor agonists, isoprenaline or salbutamol, produced a half-maximal inhibition of spontaneous motility of rat isolated proximal colon at a substantially lower concentration $\left(\mathrm{EC}_{50} 3.5 \times 10^{-9} \mathrm{M}\right)$ than those inducing $\beta_{2}$-adrenoceptor-mediated responses (relaxation of guinea-pig isolated trachea and rat uterus), and had virtually no chronotropic action $\left(\mathrm{EC}_{50}>3 \times 10^{-5} \mathrm{M}\right)$ on the guinea-pig isolated atrium (a $\beta_{1}$-adrenoceptor-mediated response) (Croci et al., 1987; Bianchetti \& Manara, 1990). Similarly, BRL 37344 relaxed guinea-pig ileum (Bond \& Clarke, 1988) and gastric fundus (Coleman et al., 1987), contracted by histamine and prostaglandin $F_{2 \alpha}\left(\mathrm{PGF}_{2 \alpha}\right)$ respectively, at concentrations which were resistant to $\beta$-adrenoceptor and $\alpha$-adrenoceptor antagonists, suggesting a specific effect on a putative $\beta_{3}$ adrenoceptor.

Our results clearly demonstrate that SR 58611A and BRL 37344 on the one hand, and salbutamol on the other hand, exert different effects on the guinea-pig isolated main bronchus. Salbutamol induced a potent relaxant effect on basal tone of the guinea-pig bronchi and inhibited the concentration-response curves to acetylcholine, $\left[\mathrm{Nle}^{10}\right] \mathrm{NKA}(4-10)$ and substance $P$. Furthermore, it greatly inhibited the two components of the neurally-mediated biphasic response observed following EFS of the guinea-pig isolated main bronchus. The first, fast component is inhibited by atropine and is associated with stimulation of cholinergic nerves. The late and prolonged second phase is NANC in nature, and is abolished or strongly reduced by antagonists of $\mathrm{NK}_{2}$-receptors, such as SR 48968 and MEN 10,207, and partially reduced by CP-96,345, an antagonist of $\mathrm{NK}_{1}$-receptors (Lundberg et al., 1983; Maggi et al., 1991; Martin et al., 1992). Both $\mathrm{NK}_{1}$ and $\mathrm{NK}_{2}$-receptors are involved in the NANC component of the guinea-pig isolated main bronchus to EFS; however, $\mathrm{NK}_{2}$ stimulation predominates, as shown by Maggi et al. (1991) and Martin et al. (1992). The effects of salbutamol were abolished or inhibited by both the nonselective $\beta$-adrenoceptor antagonist, propranolol, and by the selective $\beta_{2}$-adrenoceptor antagonist, ICI 118,551 , showing that the effects of salbutamol are due to stimulation of $\beta_{2}$-adrenoceptors. The inhibitory effects of $\beta$-adrenoceptor agonists on the cholinergic response induced by EFS or vagal stimulation have previously been described for the guinea-pig isolated bronchus (Kamikawa \& Shimo, 1990), the canine isolated bronchus (Cabezas et al., 1971; Vermeire \& Vanhoutte, 1979; Martin \& Collier, 1986; Danser et al., 1987; Ito, 1988) and for human bronchi (Rhoden et al., 1988; Aizawa et al., 1991) and they have been attributed to prejunctional inhibition because $\beta$-adrenoceptor agonists were more effective in inhibiting this response than similar contractile responses induced by exogenous acetylcholine (Vermeire \& Vanhoutte, 1979; Ito, 1988; Aizawa et al., 1991). Nevertheless, Martin \& Collier (1986) could not demonstrate that the $\beta$-adrenoceptor agonist, noradrenaline, inhibited the release of acetylcholine from cholinergic nerves in canine airways. Other studies (Kamikawa \& Shimo, 1990; Verleden et al., 1991) have also previously demonstrated the inhibitory effects of noradrenaline and $\beta_{2}$-adrenoceptor agonists (formoterol, salbutamol) on the EFS-induced NANC contraction in guinea-pig bronchi. Our present study is consistent with a postjunctional mechanism of salbutamol since we observed an inhibitory effect of this compound on cumulative concentration-response curves to acetylcholine, substance $\mathbf{P}$ and $\left[\mathrm{Nle}^{10}\right] \mathrm{NKA}(4-10)$, the latter compound being a selective agonist of $\mathrm{NK}_{2}$-receptors. However, this does not rule out an additional prejunctional component.

In contrast to salbutamol SR 58611A and BRL 37344 seemed to produce an inhibition of the NANC response predominantly at a prejunctional level. Although they might exert a small direct relaxant effect on bronchial smooth muscle, as seen against a basal tone unlike salbutamol, they did not modify the first rapid and intense cholinergic component of the contraction induced by EFS, and similarly were without effect on concentration-response curves to acetylcholine, $\left[\mathrm{Nle}^{10}\right] \mathrm{NKA}(4-10)$ or substance P. Likewise, Itabashi et al. (1992) have previously shown that BRL 37344, up to a concentration of $10^{-8} \mathrm{M}$, reduced NANC contractions without having a significant effect on similar contractions induced by exogenous substance $P$ on the guinea-pig isolated bronchus. These results are consistent with these compounds acting on presynaptic nerve endings to inhibit the release of neuropeptides from NANC fibres. A ganglionblocking effect seems unlikely since responses to EFS are not modified by ganglion-blocking agents in the canine bronchus (Vermeire \& Vanhoutte, 1979).

The partial inhibition of the effects of BRL 37344 by propranolol or ICI 118,551 suggests that a $\beta_{2}$-adrenoceptor agonistic component might be implicated in the action of BRL 37344, as was suggested by Manara et al. (1990).

Bianchetti \& Manara (1990) have reported that propranolol and alprenolol prevented the inhibition of the rat colon motility induced by SR 58611A at high concentrations $\left(\mathrm{pA}_{2}\right.$ values were around 6.5 and 7.5 respectively), whereas these drugs antagonized typical $\beta_{1}$ - and $\beta_{2}$-responses at low concentrations $\left(\mathrm{pA}_{2}\right.$ values around 9.0). Our results show that propranolol $10^{-6} \mathrm{M}$ caused little or no modification of the inhibitory effects of SR 58611A, and was only weakly effective against those of BRL 37344. It is difficult to explain the absence of activity of these antagonists at high concentration in the present study, but the existence of species variants of $\beta_{3}$-adrenoceptors might be an explanation, since Coleman et al. (1987) were unable to demonstrate any $\beta_{3}$-adrenoceptor antagonist activity with propranolol on guinea-pig fundus. Alternatively, the existence of subtypes of $\boldsymbol{\beta}_{3}$-adrenoceptors might also explain these findings.

The absence of effects of yohimbine on the inhibitory effect of BRL 37344, SR 58611A and salbutamol enables us to exclude an $\alpha_{2}$-adrenoceptor-mediated component in the inhibitory effect of these drugs.

Finally, it might have been expected that inhibition of the NANC response would result in some diminution of cholinergic response, since it has been demonstrated that tachykinins may lead to facilitation of the cholinergic response induced by direct vagal nerve stimulation or by electrical field stimulation of the guinea-pig airway (Watson et al., 1992; Belvisi et al., 1993), and capsaicin, which depletes sensory nerves, may lead to a decrease of the cholinergic response (Stretton et al., 1992). This was apparently not the case in our experiments since inhibition of the NANC response induced by $\beta$-adrenoceptor agonists resulted in no modification of the cholinergic response, in agreement with our previous results (Martin et al., 1992) where we demonstrated that SR 48968, a selective antagonist of $\mathrm{NK}_{2}$ receptors, did not modify the first cholinergic response, and atropine did not modify the second NANC response. The differences between our study and those of Belvisi et al. 
(1993), Watson et al. (1992) and Stretton et al. (1992) who demonstrated an interaction between NANC and cholinergic responses might be explained by the choice of frequency of EFS stimulation. We used $16 \mathrm{~Hz}$ in our experiments whereas the other authors used $2 \mathrm{~Hz}$ to $8 \mathrm{~Hz}$ in their studies, the differences of frequency involving responses of different intensity (30 to $40 \%$ of acetylcholine response in our result, 20 to $27 \%$ in their experiments). The interaction between the NANC and the cholinergic system seems to be observed for low frequencies of stimulation.

\section{References}

AIZAWA, H., INOUE, H., IKEDA, T., HIROSE, .T. \& ITO, Y. (1991). Effects of procaterol, a beta ${ }_{2}$-adrenoceptor stimulant, on neuroeffector transmission in human bronchial tissue. Respir., 58, $163-166$.

BARNES, P.J. (1992). Modulation of neurotransmission in airways. Physiol. Rev., 72, 699-729.

BELVISI, M.G., PATTACHINI, R., BARNES, P.J. \& MAGGI, C.A. (1993). Facilitatory effects of selective agonists for tachykinin receptors on cholinergic neurotransmission. Am. Rev. Respir. Dis., 147, A502.

BIANCHETTI, A. \& MANARA, L. (1990). In vitro inhibition of intestinal mobility by phenylethanolaminotetralines: evidence of atypical $\beta$-adrenoceptors in rat colon. Br. J. Pharmacol., 100, 831839.

BOND, R.A. \& CLARKE, D.E. (1988). Agonist and antagonist characterization of a putative adrenoceptor with distinct pharmacological properties from the $\alpha$ - and $\beta$-subtypes. Br.J. Pharmacol., 95, 723-734.

CABEZAS, G.A., GRAF, P.D. \& NADEL, J.A. (1971). Sympathetic versus parasympathetic nervous regulation of airways in dogs. $J$. Appl. Physiol., 31, 651-655.

COLEMAN, R.A., DENYER, L.H. \& SHELDRICK, K.E. (1987). $\beta$ adrenoceptors in guinea-pig gastric fundus - are they the same as the 'atypical' $\beta$-adrenoceptors in the rat adipocytes? Br. J. Pharmacol., 90, 40P.

CROCI, T., BIANCHETTI, A., POGGESI, E., BOIGERAIN, R. \& MANARA, L. (1987). Gut-specific beta adrenergic agonists inhibit rat colon mobility in vitro and in vivo. Dig. Dis. Sci., 32, 900-932.

DANSER, A.H.J., ENDE, R.V.D., LORENTZ, R.R., FLAVAHAN, N.A. \& VANHOUTTE, P.M. (1987). Prejunctional $\beta_{1}$-adrenoceptors inhibit cholinergic transmission in canine bronchi. J. Appl. Physiol., 62, 785-790.

DEVILLIER, P., ADVENIER, C., DRAPEAU, G., MARSAC, J. \& REGOLI, D. (1988). Comparison of the effects of epithelium removal and of an enkephalinase inhibitor on the neurokinin-induced contractions of guinea-pig isolated trachea. Br. J. Pharmacol., 94, 675-684.

ITABASHI, S., AIKAWA, T., SEKIZAWA, K., SASAKI, H. \& TAKISHIMA, T. (1992). Evidence that an atypical $\beta$-adrenoceptor mediates the prejunctional inhibition of non-adrenergic noncholinergic contraction in guinea-pig bronchi. Eur. J. Pharmacol. 218, $187-190$.

ITO, Y. (1988). Pre- and post-junctional actions of procaterol, a $\beta_{2}$-adrenoceptor stimulant, on dog tracheal tissue. Br. J. Pharmacol., 95, 268-274.

KAMIKAWA, Y. \& SHIMO, Y. (1990). Inhibitory effects of cathecolamines on cholinergically and non-cholinergically mediated contractions of guinea-pig isolated bronchial smooth muscle. $J$. Pharm. Pharmacol., 42, 131-134.

LUNDBERG, J.M., SARIA, A., BRODIN, E., ROSELL, S. \& FOLKERS, K. (1983). A substance $P$ antagonist inhibits vagally induced increase in vascular permeability and bronchial smooth muscle contraction in the guinea-pig. Proc. Natl. Acad. Sci. U.S.A., 80, $1120-1124$.
In conclusion, our findings show that the $\beta_{3}$-adrenoceptor agonists, SR 58611A and BRL 37344, would be expected to inhibit the release of neuropeptides from NANC fibres, while having no effect on substance $\mathrm{P}$ - and $\left[\mathrm{Nle}^{10}\right] \mathrm{NKA}(4-10)$ mediated bronchoconstriction. On the other hand, it is difficult to specify whether there is a prejunctional mechanism of the $\boldsymbol{\beta}_{2}$-adrenoceptor agonist, salbutamol. Inhibition by $\beta_{3}$-adrenoceptor agonists of neurotransmitter release from NANC nerves in airways smooth muscle may play a role in the physiological control of airways functions.

MAGGI, C.A., PATACCHINI, R., ROVERO, P. \& SANTICIOLI, P. (1991). Tachykinin receptor and noncholinergic bronchoconstriction in the guinea-pig isolated bronchi. Am. Rev. Respir. Dis., 144, 363-367.

MANARA, L., GUZZI, U., AUREGGI, G., CROCI, T. \& BIANCHETTI, A. (1990). On the selectivity of in vitro inhibition of rat colon motility by $\beta$-adrenergic substituted phenylethanolamines. Eur. $J$. Pharmacol., 183, 2197-2198.

MARTIN, C.A.E., NALINE, E., EMONDS-ALT, X. \& ADVENIER, C. (1992). Influence of ( \pm )-CP-96,345 and SR 48968 on electrical field stimulation of the isolated guinea-pig main bronchus. Eur. J. Pharmacol., 224, 137-143.

MARTIN, J.G. \& COLLIER, B. (1986). Acetylcholine release from canine isolated airway is not modulated by norepinephrine. $J$. Appl. Physiol., 61, 1025-1030.

MCLAUGHLIN, D.P. \& MACDONALD, A. (1990). Evidence for the existence of 'atypical' $\beta$-adrenoceptors ( $\beta_{3}$-adrenoceptors) mediating relaxation in the rat distal colon in vitro. $\mathrm{Br}$. J. Pharmacol., 101, 569-574.

RHODEN, K.J., MELDRUM, L.A. \& BARNES, J. (1988). Inhibition of cholinergic neurotransmission in human airways by $\boldsymbol{\beta}_{2}$-adrenoceptors. J. Appl. Physiol., 65, 700-705.

STRETTON, D., BELVISI, M.G. \& BARNES, P.J. (1992). The effect of sensory nerve depletion on cholinergic neurotransmission in guinea-pig airways. J. Pharmacol. Exp. Ther., 230, 1073-1080.

SZOLCSANYI, J. \& BARTHO, L. (1982). Capsaicin-sensitive noncholinergic excitatory innervation of the guinea-pig tracheobronchial smooth muscle. Neurosci. Lett., 34, 247-251.

UNDEM, B.J., MYERS, A.C., BARTHLOW, H. \& WEINREICH, D. (1990). Vagal innervation of guinea-pig bronchial smooth muscle. J. Appl. Physiol., 69, 1336-1346.

VERLEDEN, G.M., BELVISI, M.G., RABE, K. \& BARNES, P.J. (1991) Inhibition of non-adrenergic, non-cholinergic neural bronchoconstriction in guinea-pig airways in vitro by $\boldsymbol{\beta}_{2}$-adrenoceptors. Am. Rev. Respir. Dis., 143, A357.

VERMEIRE, P.A. \& VANHOUTTE, P.M. (1979). Inhibitory effects of catecholamines in isolated canine bronchial smooth muscle. $J$. Appl. Physiol., 46, 787-791.

WATSON, N., MACLAGAN, J., BARNES, P.J. (1992). Demonstration of a facilitatory role of endogenous tachykinins in cholinergic neurotransmission in guinea-pig trachea. Br. J. Pharmacol., 105, 78P.

WEBBER, S.E. \& STOCK, M.J. (1992). Evidence for an atypical, or $\beta_{3}$-adrenoceptor in ferret tracheal epithelium. Br. J. Pharmacol., 105, 857-862.

(Received March 5, 1993 Revised July 5, 1993 Accepted July 27, 1993) 